\title{
Development of Blended Learning Based MOODLE in Fiction Appreciation at Indonesian Language and Literature Education Study Program
}

\author{
Idawati $^{1 *}$, Salamah $^{2}$, Andri Wicaksono $^{3}$, Khaerunnisa $^{4}$ \\ 1 Indonesian Language Department, Teacher Training and Education Faculty, Muhammadiyah Lampung University, Z.A Pagar Alam Street, No. 14, Labuhan Ratu, Bandar Lampung \\ 2 Language and Art Department, STKIP PGRI Bandar Lampung, Chairil Anwar Street, Central Tj. Karang, Bandar Lampung \\ 3 Indonesian Literature Department, Universitas Muhammadiyah Jakarta, K.H. Ahmad Dahlan Street, Ciputat Tim, South Tangerang \\ 4 Indonesian Language Department, Universitas Tulang Bawang, Gajah Mada Street, No.34 Tj. Karang, Bandar Lampung
}

*Corresponding author. Email: idawati473@gmail.com

\begin{abstract}
This research aimed to produce a MOODLE learning system integrated with Blended Learning. This research is collaboration between Indonesian Language Education Programs at University of Muhammadiyah Lampung and STKIP PGRI Bandar Lampung. The object of this research were students from both universities. The method used was ADDIE methods (Analysis, Design, Develop, Implementation, and Evaluation). Learning system and material content were validated by experts. The data were collected using expert validation sheets, observations, questionnaires student and lecturer, and tests. The results showed the following things. (1) MOODLE learning system used in Fiction Appreciation learning has been validated by experts with good grades; (2) Students had positive responds to the MOODLE system developed; and (3) Blended learning based on Learning Moodle System (LMS) was very useful in improving the quality of lectures.
\end{abstract}

Keywords: Fiction Appreciation Learning, Blended Learning, MOODLE

\section{INTRODUCTION}

Since Covid-19 was declared a global pandemic by WHO, followed by many countries in the world, Indonesia through the National Disaster Management Agency (BNPB) established the status of national emergencies, then influential in all areas of life, including the national education system. The Ministry of Education in Indonesia also issued a policy that is to dismiss schools and replace the Teaching and Learning process (KBM) using an online system [1]. In addition to the scope of schools, it also influences learning in tertiary institutions, so that it also enacts Work From Home (WFH) since March 18, 2020. This makes the learning climate that was originally dominated by classical become non-classical or by Distance Learning. With this outbreak is able to accelerate the process of learning climate change including and all parties are forced to adapt quickly including the methods and ways of lecturing.

Currently learning that is usually on-site becomes online. Usually face to face to be face the screen. All interactions become completely digital. Internet networks and of course the existence of quotas become the backbone of all these processes. The conditions of Work from Home and Study from Home force all parties to strive to maximize the learning process. Therefore, Muhammadiyah University Lampung and STKIP PGRI Bandar Lampung together to commit to developing online learning in response to the "Merdeka Belajar" echo from the Ministry of Education and Culture. Allegedly, in the Academic Year 2020/2021 the learning system from pre-school education, primary and secondary education, to tertiary institutions uses the online system or Study from Home.

This emergency is not the time to put into effect complex institutional plans for distance learning that were meant to be implemented over months or years. Marfuatun explained that Online learning is a learning that uses internet, intranet, and extranet, or learning that uses non-electronic media [2]. While distance learning places more emphasis on the absence of educators at all times. Lecturers should work with what they know. Giving full attention to reassuring students is more important than trying to learn new education systems or technology on the fly [3]. To realize current technology-based learning certainly cannot be far from the internet. According to data released by the Association of Indonesian Internet Service Users (APJII), the growth of internet users in 2016, especially Indonesia in 132.7 million people based on a total population of 256.2 million people, while the 2017 APJII survey produced 143.26 million people from the total a population of 262 million people [4].

However, the facts show that the challenges in using ICT with E-learning come to their respective styles, diverse cultural, pedagogical in e-learning, ICT technology which is still minimal, technical and time management training in using ICT [5]. Utilization of Information and Communication Technology in the field of education has given birth to an electronic learning model or what is known as e-learning. E-Learning which stands for electronic learning means learning by using electronic devices, especially computer devices. In its development, e-learning is also known as on-line course, online learning, internetenabled learning, virtual learning or web-based learning [6]. 
E-learning implementation models in various categories are seen from various sides. E-learning can be classified into three models, namely adjuct, mixed / blended, and fully online [7]. Furthermore, the blended learning model places the online delivery system as an inseparable part of the overall learning process, meaning that both the face-to-face and online teaching process are a unified whole. Blended Learning is considered as a learning solution 4.0, which utilizes ICT to increase productivity (effectiveness and efficiency) while maintaining quality [8]. Therefore, we need an appropriate learning design. That is because blended learning is a combination of face-to-face in class and online, how we as educators create a relevant topic that is suitable for face-to-face in class and online. If there are some limitations in class, it can be added in online learning, which students have the same obligations as face to face in class.

Being an educator in the digital age facing this millennial generation is challenged to build effective communication, not too long to speak in one direction. Then it is necessary to prepare a presentation to be fun, attractive design and even the appearance of fashion styles must not be boring, formal but casual so that fresher also becomes a challenge. Besides being practical and building effective communication, it is also important to use technology starting from simple things such as using an automatic digital attendance list, sharing material using a cloud computing technology-based platform so that it is effective for teaching and makes it easier for students to communicate with educators.

It is critical to facilitate teacher professional collaboration and learning, and to provide teachers with access to resources and online platforms for collaboration (technology and curated education resources) so they can keep abreast of the rapidly evolving challenges and the educational and social responses that are needed, and can support learning for their students in whatever modality of deliver is feasible, ideally online [9].

From here, educators should not be reluctant and reluctant to try digital platforms, through digital platforms the distribution of tasks becomes easier and also schedules the learning process easier with the Learning Management System. Students can also easily access it through social media networks that have been created in the digital platform. Independent students learn from anywhere and anytime. In addition, with this digital platform monitoring to students becomes easy, including monitoring class activities, disciplining collecting assignments, mapping the development of learners and even setting deadlines and scoring can be automated [10]. Being an educator in the digital age facing this millennial generation is challenged to build effective communication, not too long to speak in one direction. Then it is necessary to prepare a presentation to be fun, attractive design and even the appearance of fashion styles must not be boring, formal but casual so that fresher also becomes a challenge.

Utilization of e-learning in Educational Institutions has provided benefits. The results of Marikar \& Jayarathne's research showed that the use of Moodle at General Sir John Kotelawela Defense University Srilanka received a positive response from its users and can improve student learning achievement [11]. Martín-Blas research results also revealed that the use of e-learning as a virtual space for teachers and students is effective in strengthening the knowledge and abilities of their students [12]. Then, still about Moodle in online learning, Hamdan Husein Batubara in his research revealed that the developed e-learning is considered suitable for use as a medium of learning and assessment [13].

One application that is widely used to develop e-learning sites is the Modular Object-Oriented Dynamic Learning Environment (MOODLE) application. According to D Mulhayatiah et al 2019, Moodle is a name for an application program that can transform a learning medium into a web form [14]. Moodle is a learning platform designed to provide educators, administrators, and students a websitebased learning environment that is student-oriented and maintains the principles of learning (social instructional pedagogy). This application was created by Martin Dougiamas and has made it a free application that is freely distributed and modified under the terms of the GNU General Public License.

The use of LMS must have the function of uploading and sharing materials, Forums and chats, quizzes and surveys, gathering and viewing assignments, recording grade [15]. In this study, e-learning functions as a complement or complement so that the approach used is blended learning. Blended learning is combining face-to-face learning with online learning.

This study is different from other researches done before because of the learning media in the form of using elearning based on Moodle. In their research, Bariah and Imania stated that Moodle is a Learning Management System (LMS) application that is free and can be used and modified by users based on their desires, especially teaching and learning process [16]. Elearning used by moodle version 2.7, in which it is designed based on the semester category that contains a row of courses that can be accessed by students based on the course contract. Therefore, the role of operators, managers and lecturers is needed to regulate who can access the course so that blended online learning is the same as learning in the classroom as it is.

This paper describes the stages of developing Moodle-based Blended Learning in Fiction Appreciation courses in tertiary institutions. According to Idawati and Desnia Verlinda, fiction as a literary work is the result of processed imagination that is actually lifted from the reality that exists in society [17]. It is rooted from the reality that is seen, passed, heard and even felt by an author that the processing of imagination takes place. Furthermore, Andri Wicaksono, et al. states that fiction (novel) is an imaginary reality of writers arranged in such a way from various forming elements, such as events, conflicts, figures, and so on [18]. Furthermore, in understanding the building elements of a literary work needed a positive attitude from the appreciator [19]. The process of appreciation is based on the desire to appreciate, criticize, and respond.

The author's rationale for developing Moodle as a learning and assessment system in the Indonesian Language and Literature Education Study Program departs from a survey 
of the readiness and needs of lecturers and students in using e-learning. Utilization of Information and Communication Technology will be applied in academic information systems, then implemented in the management of learning. With Moodle during the Fiction Appreciation lecture, it is hoped that there will be a change in the attitude of students to use the internet as a learning resource. Students' attitude towards the theory and practice of fiction appreciation is expected to increase because students have built their own understanding, from various learning sources, not only from lecturers as the only source of learning.

\section{METHODS}

This research used Research and Development design which referred to the development model of Analyze, Design, Development, Implement, and Evaluation (ADDIE). This model was developed by Molenda and Reiser (in Amirullah Abduh, et al (ed.) [16]. This model is often used to describe a systematic approach to instructional development. This model was chosen because the description was more complete and systematic and was the development of a model that accommodates information technology in its research flow. This research was conducted in the Fiction Appreciation Class, PBSI STKIP PGRI Bandar Lampung Study Program and Lampung Muhammadiyah University Academic Year 2019/2020. The study was conducted in April to June 2020.

According to Branch (2009), the steps in developing learning media with the ADDIE model are as follows [17].

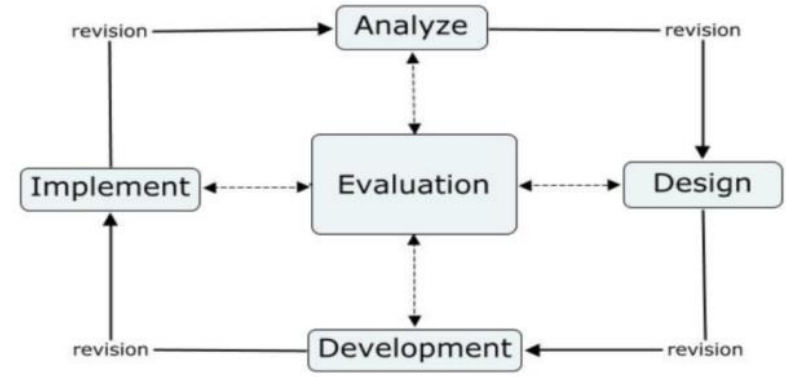

Figure 1. ADDIE Model Development Chart

The ADDIE model of learning design scheme forms a cycle consisting of 5 related stages as follows.

Analysis, the design phase of the analysis focuses on the target audience. At the analysis stage, defining instructional problems, instructional goals, learning objectives and identifying the learning environment and knowledge possessed by students are carried out.

Design, the design phase is related to goal setting, assessment instruments, exercises, content, and analysis related to learning material, learning plans and media selection. The design phase is carried out systematically and specifically.

Development, in the step of development, the creation and incorporation of content that has been designed were carried out at the design stage. In this phase, storyboarding, content writing and graphic design are required.

Implementation, this phase establishes procedures for training the trainees and their instructors / facilitators. Training for facilitators includes curriculum materials, expected learning outcomes, delivery methods and testing procedures. Other activities that must be carried out in this phase include the duplication and distribution of materials and other supporting materials, as well as preparation for technical problems and discussing alternative plans with students.

Evaluation, each stage of the ADDIE process involves formative evaluation [18]. This is multidimensional and an important component of the ADDIE process. This assumes formative evaluation form in the development stage. Evaluation is carried out during the implementation phase with the help of instructors and students.

After the learning process is completed, a summative evaluation is carried out to improve learning. The designer of all stages of evaluation must ascertain whether the problems relevant to the training program are resolved and whether the desired objectives are met.

\section{RESULT AND DISCUSSION}

\section{a. Research Result}

The result of the development of this research was the Moodle-based blended learning system in the Fiction Appreciation courses in higher education. The development of the Moodle system was based on an analysis of the need for effective and efficient learning in the Pandemic Covid19 period in tertiary institutions, more specifically in learning at the Muhammadiyah University of Lampung and STKIP PGRI Bandar Lampung. The objects of this research were students and lecturers. Data collection was obtained from interviews, questionnaires, and tests.

Based on the results of interviews with lecturers and students, it was found that students actively use the internet outside of college, most also had their own computers. Before the Covid-19 emergency period, in learning in the classroom the lecturer actively used PowerPoint slides. From this arises an obstacle, namely the limited time allocation for delivering all material to students. Another obstacle was the ability of lecturers to develop the learning system. As a result, the learning system seems to be oneway, lecturer-student or student-lecturer. When students were asked for class discussion, the results were less than optimal. Other problems included limited internet facilities, smart phones, and computer ownership. Also, there was no learning system or media that accommodates a combination of face-to-face learning and direct internet-based interaction, specifically for the Fiction Appreciation courses. The front page displayed of Moodle-based Fiction Appreciation learning was developed as follows.

At this stage the development of features used in the learning system was carried out. The learning components can be seen in table 1. From the material that has been compiled in Moodle, there are three core parts that must be arranged in Moodle management, namely appearance, 
lecture, and users. In order to be able to make settings then do the Login first using a username and password, the next step is to click "Turn Editing On".

Table 1. Content of Moodle Material Developed

\begin{tabular}{|c|c|}
\hline No. & Course Content \\
\hline 1. & Course Profile \\
\hline 2. & Learning Outcomes \\
\hline 3. & Lecturer /Tutor \\
\hline 4. & Meeting 1: Introduction to Literature \\
\hline 5. & $\begin{array}{l}\text { Meeting 2: Indonesian Literature in } \\
\text { Periodization }\end{array}$ \\
\hline 6. & $\begin{array}{l}\text { Meeting 3: Basic concepts and } \\
\text { characteristics of Prose }\end{array}$ \\
\hline 7. & Meeting 4: Theme \\
\hline 8. & Meeting 5: Plot \\
\hline 9. & Meeting 6: Characterization \\
\hline 10. & Meeting 7: Setting \\
\hline 11. & Meeting 8: Midterm Exam \\
\hline No. & Course Content \\
\hline 12. & Meeting 9: Viewpoints \\
\hline 13. & Meeting 10: Language and Stylistics \\
\hline 14. & Meeting 11: Religious and Moral Values \\
\hline 15. & $\begin{array}{l}\text { Meeting 12: Cultural Values and } \\
\text { Character Education }\end{array}$ \\
\hline 16. & $\begin{array}{l}\text { Meeting 13: Learning Materials Fiction } \\
\text { Appreciation }\end{array}$ \\
\hline 17. & $\begin{array}{l}\text { Meeting 14: Learning Fiction (Aspects of } \\
\text { Cognition and Affection) }\end{array}$ \\
\hline 18. & $\begin{array}{l}\text { Meeting 15: Learning Fiction } \\
\text { (Psychomotor Aspects) }\end{array}$ \\
\hline 19. & Meeting 16: Final Exams Semester \\
\hline 20. & Bibliography \\
\hline 21. & ig Process Sur \\
\hline 22. & Contact and Administration \\
\hline
\end{tabular}

Of the several topics that had been set in Moodle that were used as the default setting for each course that chooses to study with the Blended Learning method. Following were the contents of the material from the Moodle-based Online Lecture System that was developed before being validated. At this stage, the design of a Moodle-based media product design was carried out in the form of a Moodle-based learning system. Analysis of features in Moodle was done, namely: login and logout, courses, teaching materials, downloads, chat, discussion forums, practice questions, and exams. In general, each subject developed was shown in Figure 2.

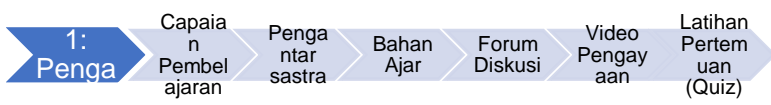

Figure 2. Each developed subject

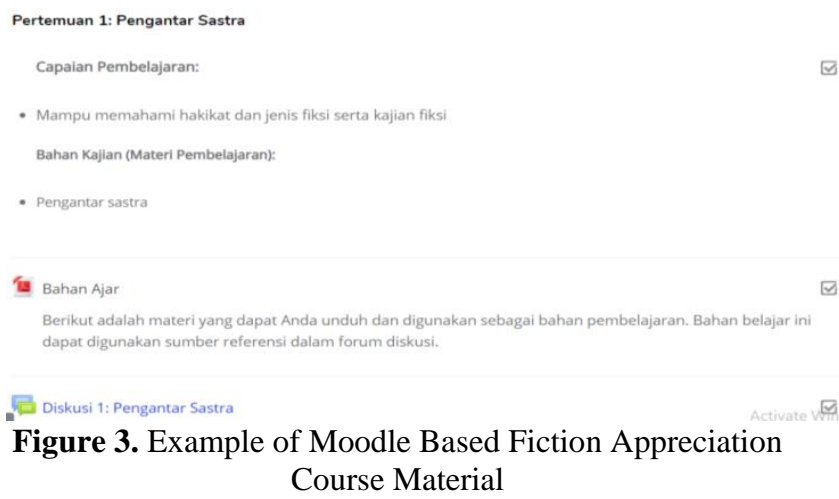

Moodle that had been developed was then validated by a media expert validator and material expert validator. The results of the development of the research instrument, obtained expert validation instrument consisting of 10 items statement. The validation results would be used as material for revision of Moodle-based online learning media. Based on the analysis of the Moodle-based learning system is 4.51, in the category was very valid $(4.5 \leq \ddot{\mathrm{x}} \geq 5)$ so that the developed Moodle was stated to meet the validity criteria. The quantitative data of the validation results can be seen in Table 2.

Table 2. Validator Ratings for Moodle Based Fiction Appreciation Learning Systems

\begin{tabular}{lllll}
\hline $\mathbf{l}$ & $\begin{array}{l}\text { Validator } \\
\text { to- }\end{array}$ & & $\begin{array}{l}\text { Total } \\
\text { Score }\end{array}$ & $\begin{array}{l}\text { Informatio } \\
\text { n }\end{array}$ \\
\cline { 2 - 3 } & I & II & & \\
1 & 4,75 & 4,5 & 4,63 & Very Valid \\
2 & 4,25 & 4,5 & 4,38 & Valid \\
3 & 4,5 & 4,5 & 4,50 & Very Valid \\
4 & 4,75 & 4,25 & 4,50 & Very Valid \\
\hline 5 & 4,5 & 4,25 & 4,38 & Valid \\
6 & 4,5 & 4,25 & 4,38 & Valid \\
7 & 4,75 & 4,5 & 4,63 & Very Valid \\
\hline 8 & 4,5 & 4,75 & 4,63 & Very Valid \\
\hline 9 & 4,75 & 4,75 & 4,75 & Very Valid \\
\hline 10 & 4,25 & 4,5 & 4,38 & Valid \\
\hline & Average & & 4,51 & Valid \\
\hline
\end{tabular}

In this validation phase, it was conducted and tested on 1 lecturer from STKIP PGRI Bandar Lampung. A summary of the results of media validation is presented in Figure 2.

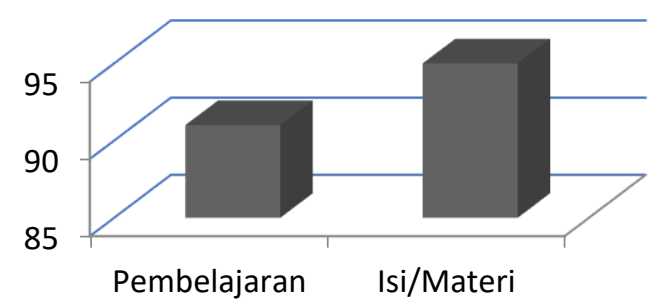

Figure 4. Validation Fiction Appreciation based Moodle Material 
Based on the results of the validation of the material that can be seen in Figure 2, it can be seen that the assessment on the learning aspect gets a value of 91 with a very decent category. As for the content / material aspects, the score is 95 which is categorized as very feasible. Therefore, for the assessment of the material experts to all aspects tested tried to get a very decent category with an average of 95.4. Thus, the Moodle system can be used as a learning medium for Fiction Appreciation.

The next stage was the implementation carried out with the application of developed Moodle. At this stage a field trial was carried out in order to obtain data on the results of the student attitude questionnaire towards the Fiction Appreciation course. While student activities in using Moodle-based online learning and student response data were obtained through surveys to find out the practicality of the media or the online learning system developed. Research data on student responded to Moodle-based learning systems is 82.5 .

Based on the results of the responses / responses from students that can be seen in Figure 3 for the results of the assessment on the motivational aspects of getting an assessment of 82 (very feasible), for the attractiveness aspect of getting an assessment of 84, categorized as very feasible. Whereas in the aspect of convenience, an assessment of 77 was considered appropriate. For the benefit aspect, it got an assessment of 79 with a decent category. Then the overall assessment of all aspects that had been tested tried to get an average of 80.5 which was categorized as very feasible.

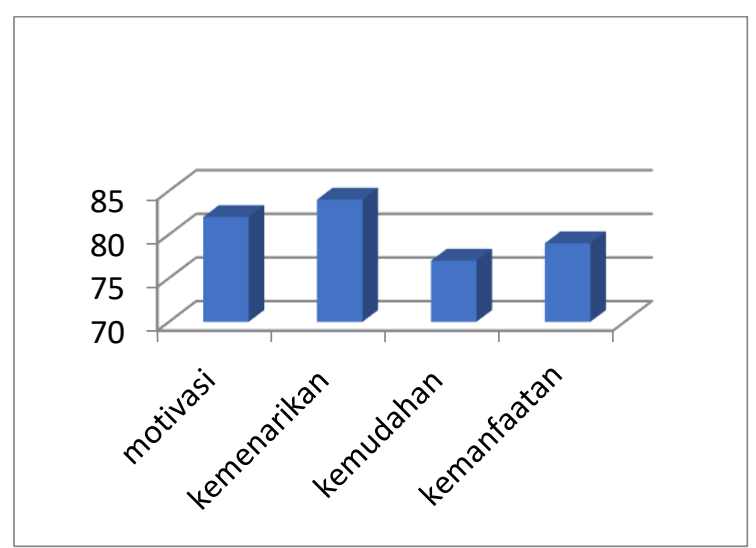

Figure 5. Students Responds

The results of the development of a Moodle-based blended learning system are declared 'feasible' to be used to support the learning process in lectures. Students gave positive responses and can increase their learning motivation. The product developed also had an advantage in improving the quality of learning that was more interesting and controlled. Lecturers and Students automatically gained better teaching and learning experience in the use of information technology.

\section{b. Discussion}

The quality of computer-assisted learning media can refer to the quality criteria according to Nieven cited by Andi
Asmawati Azis, including: (1) Validity, (2) Practically, and (3) Effectiveness (19). Media validity is a requirement that must be met before a media is implemented to the research subject. Based on the results of validation data analysis, the Moodle-based online learning system was worth testing the research object. The results of student responses showed a very positive response to the use of Moodle-based BlendedLearning. Determination of positive or not student responses was based on the categories that had been included in the research methods of the practical data analysis section.

From student activity data, it can be identified that student activities are still lacking in using some features in the media. Only the activity of downloading teaching materials, engaging in quiz activities, assessments, and student response questionnaires were accessed by 10 students, but for other activities such as glossary, wiki, downloading video, forums and chat were still lacking in access by students, only a small proportion of students access it. This could be influenced by several reasons, namely: 1) facilities and infrastructure owned by students were limited so that students have difficulty accessing the Moodle-based remote learning system to the maximum, 2) students were not accustomed to learning to use e-learning media. Improving student attitudes toward humanities and human physiology and e-learning is very important because it can affect the achievement of learning objectives. This is reinforced by Ahmad Nasr's opinion that one of the keys in learning science is the positive attitude of students towards science because it can motivate students in learning science [20]. Understanding student attitudes is important in supporting student achievement and interest in certain disciplines.

Based on the results of the study, it was found that the Moodle-based Fiction Appreciation learning system in the Indonesian Language and Literature Education Study Program was very good. The assessment focuses on assignments and evaluations for one semester. Learning media that had been developed could be a source of learning for students and help lecturers in lecturing activities [20]. From the research conducted by Andi Asmawati Azis, it was concluded that the Moodle-based e-learning learning media had fulfilled the validity criteria with a value $(\mathrm{x}=$ 4.59). Other findings are research conducted by showing the influence of Moodle-based e-learning on students' mastery of concepts. Increasing the mastery of concepts through physics learning using e-learning based on Moodle was the implication of learning using e-learning assistance presented on the website with several advantages. Elearning can improve student understanding and mastery of concepts and improve student learning attitudes.

Thus, the stages of development and application of Moodlebased Blended-Learning in the Fiction Appreciation course can be used as a source of learning for students in order to enhance students' positive attitudes towards the internet. The characteristics contained in Moodle-based learning media are very closely related to learning activities. This is consistent with the results of the research of T. Andrews and Daly (2008) who explained that Moodle media successfully supports the implementation of teaching collaboration. This study showed the influence of Moodle-based e-learning on 
the mastery of students' concepts. Increasing the mastery of concepts through physics learning using e-learning based on Moodle was the implication of learning using e-learning assistance presented on the website with several advantages. It was shown that E-learning could improve student understanding and mastery of concepts and improve.

\section{CONCLUSION}

Based on the results of the study concluded that the learning process using E-Learning Moodle Integrated with Blended Learning is effectively used in the learning process. Media and material were also valid to use in the learning process. Lecturer and student responses about the media and materials used in the learning process were very positive. The results of the validation of the material and the online learning system were valid and very positive. Then, the results of the development of Moodle media were declared appropriate to be used to support the learning process in lectures. Students gave positive responses and could increase their learning motivation. The product developed also had an advantage in improving the quality of learning that was more interesting and controlled. Lecturers and Students automatically gained better teaching and learning experience in the use of information technology.

\section{ACKNOWLEDGMENT}

Research for this paper was conducted with funding from Institute for research and community service Muhammadiyah University of Lampung. For that, we would like to express our deepest gratitude to the Chancellor of Muhammadiyah University of Lampung, Dr. Dalman, M.Pd. which provides support for participation in The 5th Progressive and Fun Education International Conference (Profunedu) held at Ahmad Dahlan University, Yogyakarta.

\section{REFERENCES}

[1] Hafida Eka Septiana 2020 "Perubahan Pembelajaran Pada Masa Pandemi", SKH Radar Semarang, 19 Juni 2020

[2] Marfuatun 2011 Variasi Proses Pembelajaran melalui Penerapan E-Learning. Yogyakarta: UNY-FMIPA.

[3] S.J. Daniel 2020 Education and the COVID-19 pandemic. Prospects. https://doi.org/10.1007/s11125020-09464-3

[4] APJII 2016 Penetrasi Pengguna Internet di Indonesia 2016. https://apjii.or.id/survei2016

[5] M Mustari, A L Hoya, M Akmansyah1, R Diani, A Asyhari 2019 Development of E-Learning Based Blogs on Global Warming Subject. IOP Conf. Series: Journal of Physics: Conf. Series 1155 (2019) 012036, oi:10.1088/1742-6596/1155/1/012036

[6] D. Darmawan 2014 Pengembangan E-Learning: Teori dan Desain. Bandung: Remaja Rosdakarya

[7] D.S Prawuladilaga, dkk. 2013 Mozaik Teknologi Pendidikan E Learning. Jakarta: Kencana Prenada Grup.
[8] Rifnida \& Andri Wicaksono (2019). Pembelajaran Sastra yang Kekinian. Prosiding Seminar Nasional STKIP PGRI Bandar Lampung, 1(1), 109-118.

[9] Fernando M. Reimers 2020 A framework to guide an education response to the COVID-19 Pandemic of 2020. Harvard: OECD.

[10] Hadi Kurniawan 2020 Peran Pendidik: Transformasi, Adaptasi dan Metamorfosis Dunia Pendidikan di Masa Pandemi Covid-19, http://www.untan.ac.id/peranpendidik

[11] F.M Marikar 2016 Effectiveness of Moodle in Education System in Srilankan University. International Journal of Modern Education and Computer Science, (8(2), 54.

[12] Teresa Martín-Blas, Ana Serrano-Fernández 2009 The role of new technologies in the learning process: Moodle as a teaching toolin Physics. Computers \& Education 52 (2009) 35-44

[13] Hamdan Husein Batubara 2017 Pengembangan Situs e-Learning dengan Moodle versi 3.1 sebagai Media Pembelajaran pada Program Studi Pendidikan Guru Madrasah Ibtidaiyah. Al-Bidayah Vol 9, No 1 (2017), $1-13$

[14] D Mulhayatiah et al 2019 Moodle-blended problem solving on student skills in learning optical devices. IOP Conf. Series: Journal of Physics: Conf. Series $1155 \quad$ (2019) 012073 doi:10.1088/1742-6596/1155/1/012073

[15] P. Prokop et al. 2007 Slovakian Students' Attitudes toward Biology. Eurasia Journal of Mathematics, Science \& Technology Education, 2007, 3(4), 287-295

[16] Siti Husnul Bariah dan Kuntum An Nisa Imania 2018 Implementasi Blended Learning Berbasis Moodle pada Jurusan Pendidikan Teknologi Informasi. Jurnal PETIK Volume 4, Nomor 2, September 2018.

[17] Idawati and Desnia Verlinda 2020 Peran Sastra Lisan Dalam Pengenalan Budaya Bangsa Indonesia. Imajeri: Jurnal Pendidikan Bahasa dan Sastra Indonesia, Vol. 02, No. 2, pp. 175-181; Maret 2020

[18] Andri Wicaksono, Emzir, and Zainal Rafli 2020 History of Indonesia's War Independence in Novel Larasati by Pramoedya Ananta Toer: New Historicism Approach. DOI: 10.5220/0008993400320040. In Proceedings of the International Conference on Education, Language and Society (ICELS 2019), pages $32-40$

[19] Salamah, Desnia Verlinda, and Idawati 2019 Kemampuan Mengidentifikasi Unsur Pembangun Teks Drama pada Siswa Kelas XI SMA Gajah Mada Bandar Lampung. Ksatra: Jurnal Kajian Bahasa Dan Sastra, 1(2), 7-26. https://doi.org/10.1983/ksatra.v1i2.370

[20] Amirullah Abduh, et al (ed.) 2018 Proceedings of The 65th TEFLIN International Conference, Universitas Negeri Makassar

[21] R.M. Branch 2009 Instructional Design-The ADDIE Approach. New York: Springer.

[22] R.M. Branch and T. J. Kopcha 2014 Instructional design models: Handbook of research on educational communications and technology (pp. 77-87): Springer.

[23] Andi Asmawati Azis 2015 Pengembangan Media ELearning Berbasis LMS Moodle Pada Matakuliah Anatomi Fisiologi Manusia. Jurnal Pendidikan Biologi, Volume 7, Nomor 1, Agustus 2015, hlm. 1- 8

[24] Ahmad Nasr. 2011. Attitude Towards Biology and Its Effect on Students Achievement. International Journal of Biology, Vol.3, No.4 Oktober 2011.

[25] T. Andrews and C. Daly. 2008. "Using Moodle, An Open Source Learning Management System, to Support a National Learning and Teaching Collaboration". Paper Presented at Proccedings of the 2008 AaeE Conference, Yeppoon copyright: Australia. pp. (1-6). 